\title{
27 \\ STATEMENT OF THE METHODIST CHURCH IN FIJI AND ROTUMA ON THE ARMED SEIZURE OF GOVERNMENT
}

\section{Iliatia Sevati Tuwere}

The Methodist Church in Fiji and Rotuma appeals to George Speight, his group and supporters to free the hostages they hold in the Parliament complex in Suva. The Church recognises and accepts the reality of the situation and speaks on the issue from this perspective. It condemns the illegal takeover of Mr Mahendra Chaudhry's government as well as the inhumane and degrading treatment of its members by being held in captivity. It denounces the destruction and looting of businesses in Suva and other areas, the loss of the life of a policeman in rioting in the city, and lawlessness in other parts of the nation. The Church extends its sympathy to members of the Indian community for being targeted in the mass attacks, destruction and looting.

The Church supports His Excellency the President, Ratu Sir Kamisese Mara, and the Great Council of Chiefs in their efforts to break the stalemate in the hostage situation and to craft a constitutional and just solution to the political crisis. We believe the President's decision to step aside for 21 days to allow martial law to be imposed in the nation is necessary, because of the rapid deterioration in the law and order situation. On our assessment, this step must be taken to impose the rule of law and to restore constitutional government. 
We are saddened and ashamed of the lawlessness and violence. We take the responsibility of failing to teach our people, who make up the majority of the perpetrators and supporters in these unlawful activities. But the Church believes something bigger is happening in this crisis - it is about cultural understanding. More effort and energy should be directed at cultivating cultural understanding. We hope that in the near future the Indian community can find forgiveness for their attackers and look beyond the anger and frustration of this moment, to explore, articulate and resolve with the indigenous people a common sense of insecurity they share in this land.

\section{Church Position}

The Church constitutes the largest Christian denomination in Fiji, most members being indigenous Fijians, and Christianity is the religion with the biggest following. This statement is issued from this position. The Methodist Church in Fiji and Rotuma wishes to make it categorically clear that its leadership is united in its condemnation of the illegal takeover of government, the destruction and looting of businesses in Suva and other parts of Fiji, the killing of a policeman and the wounding of three other people, and the general hostility directed at the Indian community. It is undivided in its support of the President and the Great Council of Chiefs in seeking a constitutional and just solution to the hostage situation and the political crisis.

\section{Theological Responses}

The Fijians being the perpetrators of these activities, the focus of this statement is on an indigenous perspective. Several theological responses may be made to the coup attempt and the lawlessness which attended this crisis. The responses relate to issues which include the following:

- the State's concern to develop multiculturalism,

- the Church theology of love and reconciliation,

- the grassroots identity question in indigenous society, 
- the distinction between what is legal and what is just,

- the tension between global standards and the specific Fiji situation,

- and the nation-state in a world of transnational corporations and agencies.

Other issues may be raised from the perspectives of Indians and other groups in this nation. Of the issues listed here, the Church believes that consideration of the indigenous identity question should be given priority, and this ought to be done responsibly as part of the solution to this crisis and to light the path to Fiji's future. This immediate statement does not address all these issues.

The impoverishment and disaffection of Fijians are evident in the large number of supporters which the hostage-takers have attracted in the Parliament grounds, enabling them to create a human shield of civilians against any armed intervention by the military. If an individual breaks the law, we might be content with a psychological explanation for his deviance. When many people take part, as they have, in unlawful activities, we must look further into society for explanation.

Former Prime Minister Mahendra Chaudhry wanted his legacy to Fiji to be a substantial improvement in the standard of living of the indigenous people. But his detractors described some of his proposals as based on dishonest motives of alienating indigenous land. The depressed indigenous economic and political condition, as a commentator has noted, is not the result of 12 months of leadership by Fiji's first Indian premier. On this view, it is the result of 30 years of modern indigenous Fijian leadership which has sacrificed the economic and cultural well-being of a people for the advancement of a few. George Speight's coup attempt and the public response to it are viewed in this perspective as a symptom of complex contradictions and competing interests facing indigenous Fijian society today.

'My name is Legion; for we are many,' (Mark 5: 9) the possessed man told Jesus Christ when He asked him his name in an exorcism story from the scriptures. The man with the unclean spirit lived among the tombs; and no one could bind him any more, even with a chain. In another 
context, however, we are told that one exorcism may not be adequate. 'And when he comes he finds it (the house) swept and put in order. Then he goes and brings seven other spirits more evil than himself, and they enter and dwell there; and the last state of that man becomes worse than the first.' (Luke 11: 25-26)

After the first two coups in 1987, a new Constitution was promulgated in 1990 and parliamentary government reinstated. A review of that Constitution was undertaken and a fresh Constitution enacted in 1997, based on the exciting vision of a truly multicultural and dynamic society. Now, in kidnapping democratically elected Prime Minister Mahendra Chaudhry and his Cabinet, it has been said, George Speight has taken hostage of much of the hope and potential Fiji had at the turn of the century to become a nation united.

\section{Indigenous Identity}

The matter of Fijian identity is a key element which is wrapped up in the current crisis of government and the rule of law. Fijian collective consciousness is made up of the inseparable union among the three strands of vanua (land), Lotu (Church) and Matanitu (State). Their union is so complete that if one is affected, the whole is affected. Vanua has physical, social and cultural dimensions which are inter-related, as a local anthropologist has pointed out. It denotes the land area one is associated with, the flora and fauna, and other objects on it. It includes the social and cultural system - the people, their traditions and customs, beliefs and values, and social institutions. Its social and cultural dimensions are a source of security and confidence. It is the locality over which the ancestral spirits linger and watch over the affairs of their living descendants. For most Fijians, to part with the vanua is tantamount to parting with their lives.

Fijians categorise the population or inhabitants of the country, or any locality or village, into two main divisions. A person is either a taukei (indigene or owner) or vulagi (visitor or foreigner) in any place. It is a relationship of mutual obligations and clearly defined roles in which one 
does not count or begrudge his or her contribution to communal life. Depending on the goodwill of the people involved, it can be a gracious partnership of host and guest, or a hostile relationship of landlord and tenant.

Methodism (the Lotu) has contributed significantly towards improving the social life of Fijians. The missionaries, like the government, enlisted the help of chiefs in their work. The Church brought peace, unity, economic and political development. Methodism gave Fijians a written language. It pioneered Fijian education at all levels: primary, secondary, adult education, Bible schools, technical, agricultural, health and vocational education. It promoted education for girls, by setting up schools for them. The vakatawa (catechists) and vakavuvuli (teachers) took the Gospel to all comers of Fiji, so that Fijians evangelised Fijians. Even while this happened, Fijian missionaries took the Good News to the Western Pacific - Papua New Guinea, the Solomons, and what is now Vanuatu.

The close relationship between vanua and Lotu during the last one and a half centuries in Fiji has always been greatly appreciated and valued for it brought about much needed unity among the Fijian people in the early days. Their link and relative harmony helped promote civilisation and well-being in islands and villages, and continues to do so. Now the indigenous people are being challenged to reconcile global standards of human rights against the specific Fijian situation. On the one hand, there is the democratic principle of 'one man, one vote and one value' and the Christian principle of equality. On the other hand, the indigenous people have cultural values of a stratified society of chiefs and commoners, confederacies and vassal provinces, and taukei and vulagi.

Three years ago, in a public statement on the constitutional review, the Methodist Church warned indigenous leaders not to be lulled by the relative harmony their people enjoy. It said that this calm could become a new form of escape from reality if the poor, the powerless and the marginalised are not justly treated. In the developing political situation, it called on Fijian leaders to move beyond the so-called point of harmony of vanua and Lotu to address the plight of the growing number of poor and powerless Fijians. 
The cleavage of the two institutions from the beginning would have been disastrous and there would not have been a Fijian race. The problem now seems to lie on the level of differentiation - in distinguishing between what is and what ought to be. The absence of such a distinction will result in the loss of a sense of direction towards the creation of community. To address this distinction must be part of the Church's contribution to the way forward for Fiji. 